\title{
Suitability and Utilization Study on Waste Plastic Brick as Alternative Construction Material
}

\author{
Tarekegn Belay Wendimu', Beneyam Neguse Furgasa ${ }^{2,}$, Bonsa Mohammed Hajji² \\ ${ }^{1}$ Department of Construction Technology and Management, College of Engineering and Technology, Mizan Tepi University, Tepi, Ethiopia \\ ${ }^{2}$ Department of Construction Technology and Management, College of Engineering and Technology, Mettu University, Mettu, Ethiopia
}

Email address:

tarekegnbelay@gmail.com (T. B. Wendimu), binicotm07@gmail.com (B. N. Furgasa), bonsmoh@gmail.com (B. M. Hajji)

${ }^{*}$ Corresponding author

\section{To cite this article:}

Tarekegn Belay Wendimu, Beneyam Neguse Furgasa, Bonsa Mohammed Hajji. Suitability and Utilization Study on Waste Plastic Brick as Alternative Construction Material. Journal of Civil, Construction and Environmental Engineering. Vol. 6, No. 1, 2021, pp. 9-12.

doi: $10.11648 /$ j.jccee.20210601.12

Received: December 29, 2020; Accepted: January 18, 2021; Published: January 25, 2021

\begin{abstract}
Construction industry is gradually increasing through the whole of the world and it is consuming natural resource raw materials for construction materials. Traditional way of producing clay brick without giving care for natural resource brought deficiency of natural resource. Now the days, plastics waste is the big challenge of the world on Environmental impacts and Alternative using High-Density Polyethylene (HDPE) plastic waste Brick for construction material is preventing environmental impact of plastic and in other hand saving natural resources clay soil. High-Density Polyethylene (HDPE) plastic waste was collected from different sites it was thrown and before producing waste plastic Brick High-Density Polyethylene (HDPE) is cleaned, and the size is minimized as it was suitable for plastic waste Brick. After that Plastic waste Bricks were produced for different Tests. five sample of plastic waste Bricks were produced for compressive strength test. Mean Compressive strength of Plastic waste Brick was 24MPa which is satisfied as per Ethiopian and ASTM standard Class A and SW grade respectively and for dimensional tolerance test, ten waste plastic Brick were taken to check dimensional change. Waste plastic Brick checked for dimensional tolerance were the same with the standard dimension as per ASTM standard. Plastic Waste Brick is not recommended for kitchen, chimney and like walling Purpose due to it has low fire resistant and melted at low temperature.
\end{abstract}

Keywords: Compressive Strength, High-Density Polyethylene (HDPE), Plastic Waste Brick

\section{Introduction}

Brick is one of the most known and beautiful building wall material as the world for long for long period of time up to now [10]. In nature plastic is a very hazardous materials which is not easily decomposed whether in the soil or water, due to this it is a huge problem in the world $[5,7]$. In this moment, all very important economic sectors started from agriculture to packaging, electrical, building construction, automobile, electronics and communication sectors [1]. Recycling is the way of using waste materials in to new products to prevent wastes of potentially useful materials. Building industry increasingly used eco-friendly, low cost and lightweight construction material brought the idea of investigating plastic waste used to environment as well as maintaining the materials as their standard [6]. Development of urbanization growth construction industry which consumes high amount of Building materials may it is natural resources or waste of different production [2]. Currently plastic waste is applicable in different ways from industrial to family consumption and it is universal range of problem solving materials [3]. According to $\mathrm{Gu}$ and Ozbakkaloglu [4], plastic waste is used as landfill or recycled for municipal solid waste. According to Jonathan and Muhammed [8], Plastic is source of carbon and there are seven types of plastics include: Polyethylene Terephthalate (PETE or PET), High-Density Polyethylene (HDPE), Polyvinyl Chloride (PVC), Low-Density Polyethylene (LDPE), Polypropylene (PP), Polystyrene or Styrofoam (PS) [9].

There are different masonry building materials, from those Brick is one of the most common masonry units. In the 
previous time Brick is produced from clay natural soil and there is imbalance between conventional buildings material and the need of the users. In other case plastic waste is largely exist as wastage and it is the biggest challenge to the environment [7].

In general, Plastic have many characteristics which include versatility, light-ness, hardness, and resistant to chemicals, water and impact [15].

\section{Material and Methodology}

\subsection{Material}

There are different types of plastic waste in Ethiopia. According to the availability of plastic waste around research area, High-Density Polyethylene (HDPE) is used for this study.

\subsection{Data Collection}

The samples of High-Density Polyethylene (HDPE) was collected from shake Zone, Tepi Town southern Ethiopia which is located $611 \mathrm{~km}$ from southern of Addis Ababa (Capital city of Ethiopia). The High-Density Polyethylene (HDPE) was collected from cafeterias and garbage in Tepi Town and it was passed through process before made plastic waste bricks.

\subsection{Preparation of High-Density Polyethylene (HDPE) for Brick Production}

In this research, High-Density Polyethylene (HDPE) plastic waste was collected from different areas of Tepi Town and in order to make suitable for plastic waste Brick production, first unwanted material was removed from HighDensity Polyethylene (HDPE) plastic waste manually and properly washed to clean different chemicals previously packed in it and other things which affect while it was melt. After it was dried manually crashed or reduced the size of High-Density Polyethylene (HDPE) plastic waste as in Figure 1.

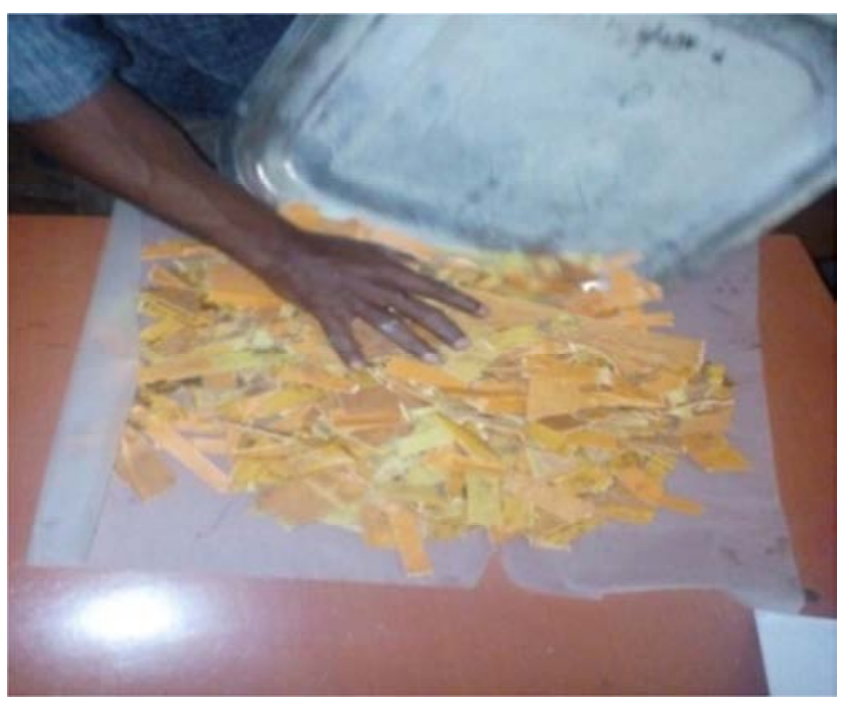

Figure 1. Reduced Size of High-Density Polyethylene (HDPE).

\subsection{Moulding of High-Density Polyethylene (HDPE) Plastic Waste}

A wooden mould was made according to Ethiopian standard (ES) with the $24 \mathrm{~cm} \mathrm{X} 12 \mathrm{~cm} \mathrm{X} 6 \mathrm{~cm}$ with internal dimension. The mould was open at the top to produce the plastic waste bricks as easily. The High-Density Polyethylene (HDPE) plastic waste was melted at the temperature of $130^{\circ} \mathrm{C}$ for 20 minutes to one hour [11], after that the melted High-Density Polyethylene (HDPE) plastic waste was filled in the mould and compacted by hummer to avoid porous which is affect the strength of waste plastic brick as Figure 1. Five samples of plastic Bricks were as per Ethiopian and ASTM standard for checking compressive strength plastic Bricks [12, 13].

Ethiopian Standard Specification

Bricks are classified according to the laboratory test results means and individuals of compressive strength, water absorption and saturation coefficient, according to Ethiopian standard ES 86 given in the Table 1.

Table 1. Minimum Compressive Strength of Solid Clay-Bricks [12].

\begin{tabular}{lll}
\hline \multirow{2}{*}{ Class } & Minimum compressive strength & \\
\cline { 2 - 3 } & Average of five Bricks $\left(\mathbf{N} / \mathbf{m m}^{2}\right)$ & Individuals of five bricks $\left.\mathbf{~} / \mathbf{m m}^{\mathbf{2}}\right)$ \\
\hline A & 20 & 17.5 \\
B & 15 & 12.5 \\
C & 10 & 7.5 \\
D & 7.5 & 5 \\
\hline
\end{tabular}

The American Society for Testing and Materials; Standard Specification for Building Bricks

According to ASTM [13], standard specification for building bricks, clay bricks are classified based on their compressive strength, water absorption and saturation coefficient as shown in the Table 2.

Table 2. Classification of Clay Bricks based on their Physical requirements [13].

\begin{tabular}{lll}
\hline \multirow{2}{*}{ Designation } & \multicolumn{2}{l}{ Minimum compressive strength, gross area (MPa) } \\
\cline { 2 - 3 } & Average of Five bricks & Individual of five Bricks \\
\hline Grade SW & 20.7 & 17.2 \\
Grade MW & 17.2 & 15.2 \\
Grade NW & 10.3 & 8.6 \\
\hline
\end{tabular}


According to ASTM standard [13], there are three grade brick, Grade SW (Sever weathering) - bricks intended for use where high and uniform resistance to damage caused by cyclic freezing desired and where the brick may be frozen when saturated with water. Grade MW (Moderate weathering) - bricks intended for use where moderate resistance to cyclic freezing damage is permissible or where the brick may be damp but not saturated with water when freezing occurs. Grade NW (Negligible weathering).

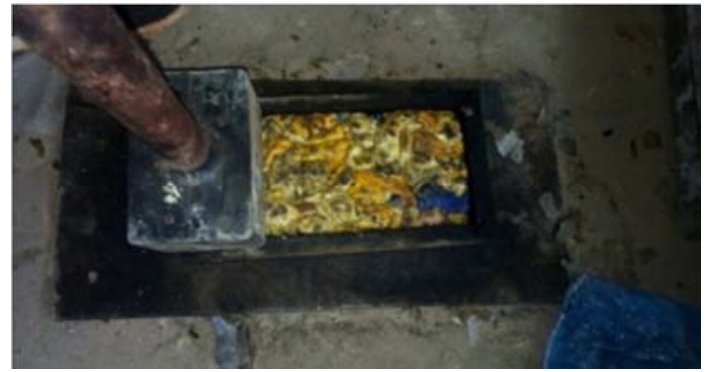

Figure 2. Compaction of Melted HDPE Plastic Waste in Mould.

\subsection{Drying}

It is the process of cooling two days in order to remove gases form casted plastic bricks before taken to compressive strength tests Figure 3.

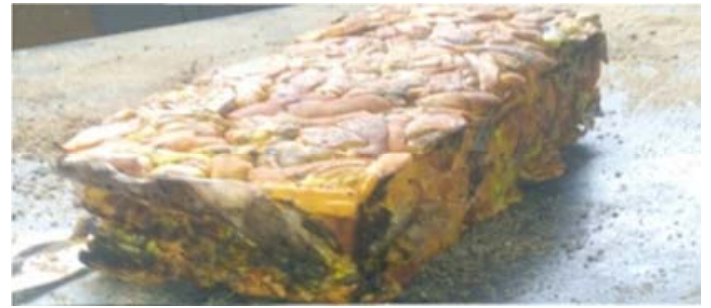

Figure 3. Produced HDPE Plastic Brick.

\subsection{Experimental Tests for Cooled Plastic Bricks}

\subsubsection{Compressive Strength}

The aim of this test was to determine the compressive strength of plastic waste bricks and Compressive strength was the only mechanical property used in normal brick specification; it is the failure stress measured normal to the bed face. Before taking the produced sample of Plastic bricks, the face bed is capped to reduce the effects of roughness of the plastic bricks and each types of plastic bricks were inserted between the upper and lower plates by kept the center line of the compression machine plates and on the machine as indicated in Figure 4 and five plastic bricks were taken for compressive strength test and the results were taken average and individual according to the Eq. 1.

$$
\text { Compressive strength }=\frac{\text { Crushing Load }(\mathrm{KN})}{\text { Area of Brick }}
$$

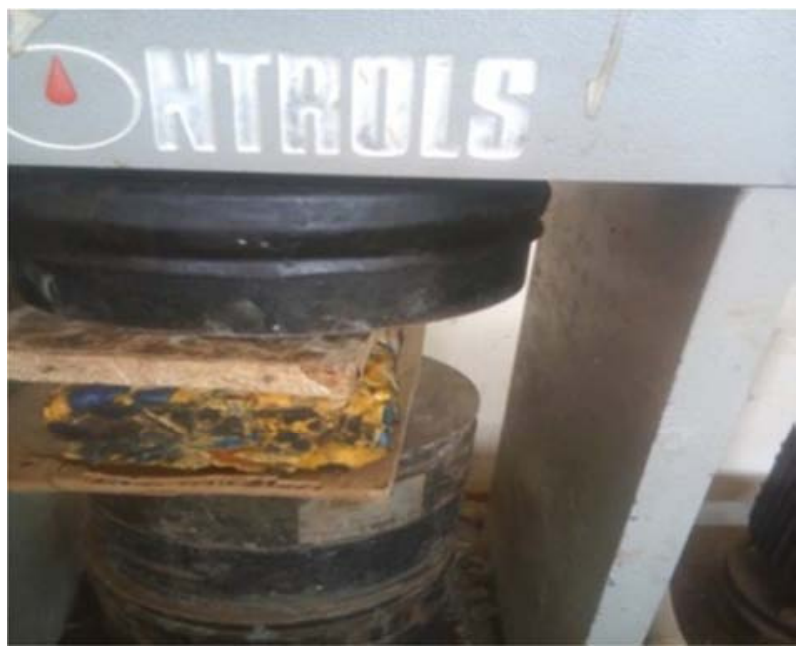

Figure 4. Compressive Strength Test for Plastic Brick.

\subsubsection{Dimensional Tolerance}

The dimension tolerance test for this study conducted as per the procedures of ASTM. For this study all the plastic waste bricks are considered as FBS (brick for general use in masonry) by taking ten plastic waste bricks and measuring the length, width and height of each plastic waste brick and the dimension was checked if it's within the ASTM C216 standard limit [14].

Table 3. ASTM standards on dimension tolerance of bricks [14].

\begin{tabular}{lllll}
\hline \multirow{2}{*}{$\begin{array}{l}\text { Specified dimension or } \\
\text { average brick size (mm) }\end{array}$} & \multicolumn{3}{l}{ Maximum permissible variation in (mm) plus or minus from } \\
\cline { 2 - 5 } & \multicolumn{2}{l}{ Column A (for specified) } & \multicolumn{2}{c}{ Column B (for average bricks size in job lot sample) } \\
\cline { 2 - 5 } & Type FBX & Type FBS & Type FBX & Type FBS (smooth) \\
\hline 76 and under & 1.2 & 2.4 & 1.6 & 1.6 \\
76 to 102 & 2.4 & 3.2 & 1.6 & 2.6 \\
102 to 152 & 3.2 & 4.8 & 2.4 & 2.4 \\
152 to 203 & 4.0 & 6.4 & 2.4 & 3.2 \\
203 to 305 & 5.6 & 7.9 & 3.2 & 4.8 \\
305 to 406 & 7.1 & 9.5 & 4.8 & 6.4 \\
\hline
\end{tabular}

\section{Result and Discussion}

\subsection{Compressive Strength}

According to compressive strength result taken from compression test machine, individual and Mean result of plastic waste Bricks were all most have relatively the same. Individual and mean sample were compared with Ethiopian and ASTM standard of Brick and all sample of waste plastic Brick produced satisfy Class A and SW grade which is used for walling materials purpose as per Table 3. Due to the 
capacity of fire resistant and melting temperature of plastic is

chimney and like walling Purpose.

low, Plastic Waste Brick is not recommended for kitchen,

Table 4. Individual and Mean compressive strength of plastic Bricks compared with ES and ASTM and their classification.

\begin{tabular}{lllll}
\hline Plastic Brick & & & Ethiopian Standard Brick [13] & ASTM [14] \\
\hline Description & Individual Compressive Strength in (MPa) & Mean compressive strength in (MPa) & Class of Brick & Class of Brick \\
\hline Plastic Brick 1 & 23.5 & & A & SW \\
Plastic Brick 2 & 25 & & A & SW \\
Plastic Brick 3 & 24.5 & 24 & A & SW \\
Plastic Brick 4 & 24 & & A & SW \\
Plastic Brick 5 & 23 & A & SW \\
\hline
\end{tabular}

\subsection{Dimensional Tolerance}

This test is to determine the effect of dimension change after it was dried/cooled dimension with the standard original dimension. The relationship of bricks dimension before and after cooled not varied and it satisfy the standard for construction purpose.

\section{Conclusion}

Waste plastic is one of world environmental challenge due to it is not decomposed whether in soil and water. Alternatively, using High-Density Polyethylene (HDPE) plastic waste Brick for construction material is preventing environmental impact of plastic and in other hand saving natural resources clay soil.

Compressive strength of Plastic waste Brick was satisfied as per Ethiopian and ASTM standard which was fall under the Class A and SW grade and Plastic Waste Brick is not recommended for kitchen, chimney and like walling Purpose due to it has low fire resistant and melted at low temperature.

\section{Acknowledgements}

We would like thanks to Mizan Tepi University, College of Engineering and Technology, Department of Construction Technology and Management help us during production of plastic waste Brick and laboratory tests.

We would also like to thanks Mizan Tepi University, Department of Construction Technology and Management students who collect HDPE plastic waste for us.

\section{References}

[1] Anzila C Bismi O M, Merin Paul, Safeeda V A, Ann Maria Jose, Utilization of Plastic Waste in Road Pavement, International Journal of Engineering Research \& Technology (IJERT), www.ijert.org. (2016), Volume 4, Issue 13, ISSN: 2278-0181.

[2] Siti Nabilah A, Nur Zulaikha Y. Plastic in Brick Application. Tr Civil Eng \& Arch 3 (1) - 2018.TCEIA.MS.ID.000152. DOI: 10.32474/ TCEIA.2018.03.000152.

[3] M A Kamaruddin, M M A Abdullah, M H Zawawi, M R R A Zainol, Potential use of Plastic Waste as Construction Materials: Recent Progress and Future Prospect, IOP Conf. Series: Materials Science and Engineering 267 (2017) 012011 doi: 10.1088/1757-899X/267/1/012011
[4] Gu, L., T. Ozbakkaloglu, Use of recycled plastics in concrete: A critical review. Waste Management, 2016. 51: p. 19-42.

[5] S. M. Leela Bharathi, V. Johnpaul, R. Praveen Kumar et al., Experimental investigation on compressive behaviour of plastic brick using M Sand as fine aggregate, Materials Today: Proceedings, https://doi.org/10.1016/j.matpr.2020.10.252.

[6] Rajarapu Bhushaiah, Shaik Mohammad, D. Srinivasa Rao, Study of Plastic Bricks Made From Waste Plastic, International Research Journal of Engineering and Technology (IRJET), www.irjet.net, (2019), Volume 06, Issue 04, e-ISSN: 2395-0056, p-ISSN: 2395-0072.

[7] R. S. Kognole | Kiran Shipkule | Kiran Shipkule | Manish Patil | Lokesh Patil | Udaysinh Survase "Utilization of Plastic waste for Making Plastic Bricks" Published in International Journal of Trend in Scientific Research and Development (ijtsrd), ISSN: 24566470, Volume-3 | Issue-4, 2019, pp. 878-880, URL: https://www.ijtsrd.c om/papers/ijtsrd23 938.pdf.

[8] Jonathan Taaffe, Seán O'Sullivan, Muhammad Ekhlasur Rahman, Vikram Pakrash Expermental characterisation of polyethylene Terephthalate (PET) bottle Eco bricks, Materials and Design, (2014), www.elsevier.com, http://dx.doi.org/10.1016/j.matdes. 2014.03.045 0261-3069.

[9] Benny T. K, Ashwin J Wilson, Anandhu M. Nair, B Dayanand Krishn, Jaseer Khan Jaleel Rasheed, Asphalt Plasto A Brick from Waste Plastic, International Journal of Engineering Research \& Technology (IJERT), http://www.ijert.org, (2019), Vol. 8, Issue 07, July-2019 ISSN: 2278-0181.

[10] Jan Fiala, Milan Mikolas, Katerina Krejsova, Full Brick, History and Future (2019) IOP Conf. Ser. Earth Environ. Sci. 221 012139, doi: 10.1088/1755-1315/221/1/012139.

[11] Isabel N. Contreras, Jenna Bader, Patricia DuRant, Lonny Grafman, An Analysis of Recycling High Density Polyethylene with Limited Resources, International Journal for Service Learning in Engineering, Humanitarian Engineering and Social Entrepreneurship, (2018), Vol. 13, No. 2, pp. 45-68, ISSN 1555-9033.

[12] Ethiopian standard ES 86, Solid clay bricks, (2001). In E. S. (ESA), Ethiopian Standard second edition.

[13] ASTM C62-97a. A. C. (1999). Standard specification for building bricks (solid Masonry units made from clay or shale). In Annual book of ASTM standard Vol. 04.05.

[14] ASTM C216-10. (2010). Standard Specification for facing brick (solid masonry units made from clay or shale.

[15] Jalaluddin M. Use of plastic waste in civil constructions and innovative decorative material (eco-friendly). MOJ Civil Eng. 2017; 3 (5): 359-368. DOI: 10.15406/mojce.2017.03.00082. 